\title{
Familial dysfibrinogenemia
}

INSERM

\section{Source}

INSERM. (1999). Orphanet: an online rare disease and orphan drug data base. Familial dysfibrinogenemia. ORPHA:98881

Familial dysfibrinogenemia is a coagulation disorder characterized by a bleeding tendency due to a functional anomaly of circulating fibrinogen. 